\title{
ANALISIS KINERJA KINERJA PEGAWAI GURU SD NEGERI 2 SUMBER JAYA KECAMATAN WAWAY KARYA KABUPATEN LAMPUNG TIMUR
}

\author{
Andy Fitriyadi Dharma Tilaar \\ Sekolah Tinggi Ilmu Ekonomi Gentiaras Bandar Lampung \\ Email: Ms006zeta2001@yahoo.com
}

\begin{abstract}
Guidance by the principal in the employees, especially on SD Negeri 2 Sumber Jaya Kecamatan Waway Karya Kabupaten Lampung Timur has been regulated in the Act, Rules and Regulations Regional Government and its implementation, but many still encountered obstacles that cause problems with various effects in order to apply principles Work Motivation principle, in order to improve employee performance such as teacher discipline, dedication, loyalty, and others. It attracted writers for further research and study a research topic "Effects of Leadership Style and Work Motivation Against Employee Performance on SD Negeri 2 Sumber Jaya Kecamatan Waway Karya Kabupaten Lampung Timur ". The focus of research on leadership, motivation Work, and employee performance.

This research was conducted using a survey method. The population is All staff of 30 people, in which samples were taken using saturated sample. The reliability of the instruments is calculated by the formula product moment correlation, while the reliability of the instruments is calculated by the formula Alpha crobach, and using multiple regression analysis

The result showed leadership style and work motivation have a great influence $(97.2 \%)$ on employee performance with variable work motivation as the dominant variable affecting employee performance with the effect of (96.2\%) but can not eliminate the variable leadership style despite having contributed negatively due valid.
\end{abstract}

Keywords: Leadership, Motivation Work, Employee Performance

\section{PENDAHULUAN}

\subsection{Latar Belakang}

Aspek penting dari peran kepemimpinan dalam pendidikan adalah memberdayakan para guru dan memberikan wewenang yang luas untuk meningkatkan kinerja pegawai sehingga proses pembelajaran para pelajar dapat mencapai hasil yang optimal. Maka peran Kepala Sekolah khususnya SD Negeri 2 Sumber Jaya Kecamatan Waway Karya Kabupaten Lampung Timur ikut serta mensukseskan tugas pokoknya sesuai dengan fungsinya dalam tugas umum pemerintahan dan pembangunan di lingkungan Pemerintah Kabupaten Lampung Timur khususnya dunia pendidikan.

Untuk itu peranan Motivasi Kerja pimpinan dalam meningkatkan kinerja pegawai di lingkungan SD Negeri 2 Sumber Jaya Kecamatan Waway Karya Kabupaten Lampung
Timur sangat dibutuhkan, guna terlaksananya mutu pendidikan. Tetapi tidak sejalan dengan yang dihadapi dalam penelitian ini dan hal ini tergambar dari gambar berikut:

\section{Gambar 1.}

Pendapat Guru Tentang Pimpinan Di Sekolah

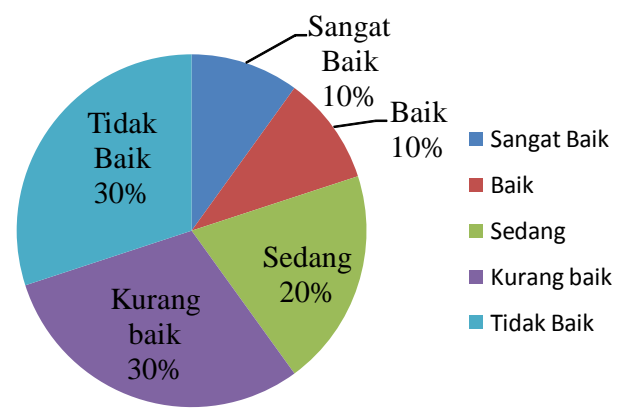

Sumber: Jejak pendapat SD Negeri 2 Sumber Jaya Kecamatan Waway Karya Kabupaten Lampung Timur 
Kondisi tersebut tidak selalu terjadi dan sesuai dengan kenyataan di lapangan disebabkan dari beberapa permasalahan yang terjadi salah satunya adalah kepemimpinan dan motivasi kerja kepala sekolah dalam bentuk insentif sangat mempengaruhi terhadap kinerja pegawai. Manajemen sekolah saat ini memiliki kecenderungan ke arah school based management. Agar otonomi pendidikan berhasil dengan baik, kepemimpinan kepala sekolah perlu diberdayakan. Dengan proses dan program pemberdayaan, mereka akhirnya harus memiliki kinerja yang profesional dan fungsional. Sebagai manajer yang baik, kepala sekolah harus mampu mengatur agar semua potensi sekolah dapat berfungsi secara optimal dalam mendukung tercapainya tujuan sekolah. Hal ini dapat dilakukan jika kepala sekolah mampu melakukan fungsi-fungsi manajemen dengan baik yang meliputi perencanaan; pengorganisasian; pengarahan; dan pengawasan.

Pembinaan oleh kepala sekolah di lingkungan pegawai khususnya SD Negeri 2 Sumber Jaya Kecamatan Waway Karya Kabupaten Lampung Timur telah diatur dalam Undang-Undang, Peraturan Pemerintah maupun Peraturan Daerah dan pelaksanaannya, namun masih banyak ditemui hambatan yang menimbulkan masalah dengan berbagai pengaruhnya dalam rangka menerapkan prinsip-prinsip Motivasi Kerja, guna meningkatkan kinerja pegawai seperti disiplin guru, dedikasi, loyalitas, dan lainlainnya. Guna memecahkan masalah di bidang pembinaan kepala sekolah di lingkungan Guru SD Negeri 2 Sumber Jaya Kecamatan Waway Karya Kabupaten Lampung Timur, sebagai acuan penulis materi kepemimpinan dan Motivasi Kerja kepala sekolah yang belum dapat terlaksana secara baik dan diduga sangat berpengaruh kinerja pegawai.

\subsection{Perumusan Masalah}

1. Apakah gaya kepemimpinan berpengaruh terhadap kinerja guru di Sekolah Dasar Negeri 2 Sumber Jaya Kecamatan Waway Karya Kabupaten Lampung Timur?

2. Apakah motivasi kerja berpengaruh terhadap kinerja guru di Sekolah Dasar
Negeri 2 Sumber Jaya Kecamatan Waway Karya Kabupaten Lampung Timur?

3. Apakah gaya kepemimpinan dan motivasi kerja berpengaruh terhadap kinerja guru di Sekolah Dasar Negeri 2 Sumber Jaya Kecamatan Waway Karya Kabupaten Lampung Timur?

\subsection{Tujuan Penelitian}

1. Ingin mengetahui sejauhmana gaya kepemimpinan berpengaruh terhadap kinerja guru di Sekolah Dasar Negeri 2 Sumber Jaya Kecamatan Waway Karya Kabupaten Lampung Timur.

2. Ingin mengetahui sejauhmana motivasi kerja terhadap kinerja guru di Sekolah Dasar Negeri 2 Sumber Jaya Kecamatan Waway Karya Kabupaten Lampung Timur.

3. Ingin mengetahui sejauhmana gaya kepemimpinan berpengaruh terhadap kinerja dan motivasi kerja terhadap Kinerja guru di Sekolah Dasar Negeri 2 Sumber Jaya Kecamatan Waway Karya Kabupaten Lampung Timur.

\section{TINJAUAN PUSTAKA}

\subsection{Gaya Kepemimpinan.}

Dalam suatu organisasi kepemimpinan merupakan suatu faktor yang menentukan tercapai atau tidaknya tujuan suatu organisasi, dengan kepemimpinan yng baik, proses manajemen akan berjalan lancar dan karyawan bergairah melaksanakan tugas-tugasnya. Gairah kerja, produktivitas kerja dam proses manajemen suatu lembaga atau organisasi akan baik jika tipe, cara atau gaya kepemimpinan yang diterapkan pimpinannya baik.

Definisi kepemimpinan menurut beberapa ahli diantaranya sebagai berikut : Menurut Hanson dalam (Masaong, 2011), menyatakan bahwa: Kepemimpinan dipahami sebagai konsep yang didalamnya mengandung makna bahwa ada suatu proses kekuatan yang datang dari seorang figur pemimpin untuk mempengaruhi orang lain baik secara individu maupun kelompok dalam suatu organisasi.

Menurut Cohen, (2011) menyatkan bahwa; Kepemimpinan diartikan sebagai kemampuan/kecerdasan mendorong sejumlah 
orang agar bekerja sama dalam melaksanakan kegiatan - kegiatan yang terarah pada tujuan bersama."

\section{Menurut}

Siagian,

mengemukakan bahwa; Kepemimpinan adalah kemampuan seseorang untuk mempengaruhi orang lain (para bawahannya) sedemikian rupa sehingga orang lain itu mau melakukan kehendak pemimpin meskipun secara pribadi hal itu mungkin tidak disenanginya.

Berdasarkan definisi-definisi tersebut dapat diartikan bahwa kepemimpinan merupakan kemampuan lebih yang dimiliki oleh seseorang untuk mempengaruhi kegiatankegiatan seseorang atau kelompok, agar orang bersedia bekerja secara efektif dan efisien dalam mencapai tujuan yang telah ditentukan pada situasi tertentu. Setiap pemimpin dapat memiliki gaya kepemimpinan yang berbeda antara satu dengan yang lainnya dan tidak harus suatu gaya kepemimpinan itu lebih baik atau kurang baik daripada gaya kepemimpinan lainnya. Dasar yang sering dipergunakan dalam mengelompokkan gaya kepemimpinan yang ada adalah tugas yang dirasakan harus dilakukan oleh pemimpin, kewajiban yang pemimpin harapkan diterima oleh bawahan dan lain sebagainya.

Dalam penelitian ini konsep Gaya Keemimpinan yang digunakan adalah yang dikemukakan oleh Kartono (2008:57) yang menyatakan bahwa "Gaya kepemimpinan adalah kegiatan mempengaruhi orang-orang agar mereka mau bekerja sama untuk mencapai tujuan yang diinginkan." Untuk mengukur kepemimpinan dalam penelitian ini dikembangkan dari teori kepemimpinan situasional Paul Hersey dan Ken Blanchard dalam Robbins (2012) yang terdiri dari 3 (tiga) indikator Kepemimpinan, yaitu :

1. Kemampuan memberikan ide-ide kepada anggota

2. Kemampuan berpartisipasi dengan anggota

3. Kemampuan mendelegasikan kepada anggota

\subsection{Motivasi Kerja}

Motivasi mempersoalkan bagaimana cara mengarahkan daya dan potensi bawahan agar amu bekerja sama secara produktif berhasil mencapai dan mewujudkan tujuan yang telah ditentukan. Berikut di bawah ini definisi tentang Motivasi menurut beberapa ahli. Motivasi menurut Rivai (2011:455); Motivasi adalah serangkaian sikap dan nilainilai yang mempengaruhi untuk mencapai hasil yang spesifik sesuai dengan tujuan individu.

Menurut Liang Gie yang dikutip oleh Mangkunegara. (2009); Motivasi adalah pekerjaan yang dilakukan oleh seorang manajer dalam memberikan inspirasi, semangat dan dorongan kepada oranglain, dalam hal ini karyawannya, untuk mengambil tindakan-tindakan. Menurut Syamsuddin. (2013:227); Motivasi Kerja diartikan sebagai keseluruhan proses pemberian dorongan/rangsangan kepada karyawan sehingga mereka bersedia bekerja dengan rela tanpa dipaksa.

Dari definisi-definisi di atas maka dapat disimpulkan bahwa motivasi adalah suatu dorongan yang timbul dari diri seseorang di dalam usaha memenuhi kebuituhannya baik secara riil maupun materiil, dan menyalurkan perilaku individu tersebut ke arah pencapaian suatu tujuan. Dalam penelitian ini konsep motivasi kerja yang digunakan adalah Menurut Syamsuddin. (2013:227); Motivasi Kerja diartikan sebagai keseluruhan proses pemberian dorongan atau rangsangan kepada karyawan sehingga mereka bersedia bekerja dengan rela tanpa dipaksa." Kemudian diukur dalam indikator motivasi kerja menurut Hamalik (2007:222) :

1. Motivasi Positif (Incentive Positive). Dalam motivasi positif, manajer memotivasi (merangsang) bawahan dengan memberikan hadiah kepada mereka yang berpartisipasi di atas prestasi standar.

2. Motivasi Negatif (Incentive Negative). Dalam motivasi negatif, manajer memotivasi (merangsang) bawahan dengan standar, apabila bawahan tidak dapat memenuhi standar kerja yang telah ditetapkan oleh manajer maka mereka akan mendapatkan hukuman. 


\subsection{Kinerja Pegawai}

Untuk mengetahui apakah individu - individu dalam organisasi yang dipimpin sudah memenuhi kriteria efektif atau belum, maka diperlukan suatu pengukuran, pengukuran dapat dilakukan jika dimiliki instrumen yang memadai. Hasil pengukuran tersebut kemudian dibandingkan dengan suatu tolak ukur atau standar. Berkaitan dengan penelitian yang akan dilakukan, maka peran dari individu sangat menentukan, sehingga uraian mengenai keefektifan hanya akan dibahas pada tingkat individu Robin, (2010).

Banyak definisi atau pengertian mengenai Kinerja pegawai, pengertian yang satu kadang berbeda atau bahkan bertentangan dengan pengertian yang lain, sehingga secara umum belum ada kata sepakat mengenai pengertian Kinerja pegawai, oleh sebab itu jika kita berbicara mengenai Kinerja pegawai akan muncul suatu situasi yang bertentangan (Paradoksial).

Greenberg yang dikutip oleh Siagian (2012:18) mendefinisikan Kinerja pegawai sebagai perbandingan antara totalitas pengeluaran pada waktu tertentu dibagi dengan totalitas masukan selama periode tersebut. Kinerja pegawai juga diartikan sebagai tingkatan efisiensi dalam memproduksi barang dan jasa, Kinerja pegawai mengutarakan cara pemanfaatan secara baik terhadap sumber-sumber dalam memproduksi barang dan jasa. Kinerja pegawai dalam organisasi adalah sejauh mana sumbangan dalam organisasi itu dapat mencapai tujuan atau sasaran organisasi.

Dalam Penelitian ini kinerja pegawai mengutip konsep yang dikemukakan oleh Greenberg yang dikutip oleh Siagian (2012) mendefinisikan

Kinerja pegawai sebagai "Kemampuan pegawai dalam memberikan kemampuannya pada organisasi untuk dapat mencapai tujuan atau sasaran organisasi." Dengan indikator pencapaian konsep adalah sebagai berikut:

1. Kualitas kerja, yaitu penyelesaian pekerjaan yang dikaitkan dengan ketelitian, kecermatan, kesesuaian standar dan lain sebagainya.
2. Kuantitas kerja, yaitu penyelesaian pekerjaan yang dikaitkan dengan waktu, volume pekerjaan, lembur dan sebagainya.

3. Tanggung jawab, yaitu penyelesaian pekerjaan yang dikaitkan dengan skill, inisiatif, Budaya Organisasi dalam mengikuti tata kerja yang ada dan lain sebagainya.

\subsection{Hipotesis Penelitian}

1. Diduga gaya kepemimpinan berpengaruh terhadap kinerja berpengaruh terhadap kinerja guru pada SD Negeri 2 Sumber Jaya Kecamatan Waway Karya Kabupaten Lampung Timur.

2. Diduga motivasi kerja berpengaruh terhadap kinerja guru pada SD Negeri 2 Sumber Jaya Kecamatan Waway Karya Kabupaten Lampung Timur.

3. Diduga gaya kepemimpinan berpengaruh terhadap kinerja dan motivasi kerja secara bersama-sama (simultan) berpengaruh terhadap kinerja guru pada SD Negeri 2 Sumber Jaya Kecamatan Waway Karya Kabupaten Lampung Timur.

\section{METODOLOGI PENELITIAN}

\subsection{Jenis Penelitian}

Dalam penelitian ini, penulis menggunakan metode Deskriptif. Menurut Sugiono, (2010:63), mengatakan bahwa metode Deskriptif adalah suatu metode dalam meneliti status, sekelompok manusia, suatu objek, suatu sistem pemikiran ataupun suatu kelas peristiwa pada masa sekarang." Tujuan penelitian dengan metode metode Deskriptif ini adalah untuk membuat deskripsi, gambaran, atau lukisan secara sistematis, faktual, dan akurat mengenai fakta-fakta, sifat-sifat serta bubungan antar fenomena yang diselidiki.

Penelitian ini untuk mengukur dan menganalisis besar pengaruh Gaya Kepemimpinan dan Motivasi Kerja Guru pada SD Negeri 2 Sumber Jaya Kecamatan Waway Karya Kabupaten Lampung Timur pada kajian Kinerja Guru. Adapun variabel dalam penelitian ini sebagai berikut :

1. Variabel bebas (X1) gaya kepemimpinan dan (X2) motivasi kerja 
2. Variabel terikat $(Y)$ kinerja guru pada $S D$ Negeri 2 Sumber Jaya Kecamatan Waway Karya Kabupaten Lampung Timur.

\subsection{Metode Pengumpulan Data}

Data yang diperlukan dalam melakukan penelitian ini meliputi data primer dan data sekunder. Dalam penelitian ini juga metode pengumpulan data yang diperlukan menggunakan teknik Wawancara, Kuesioner dan Studi Kepustakaan dan Dokumentasi.

\subsection{Metode Penetapan Sampel}

Menurut Arikunto (2012), Unit Analisis adalah satuan tertentu yang diperhitungkan sebagai subyek penelitian, dengan demikian, unit analisis dalam penelitian ini adalah keseluruhan guru di SD Negeri 2 Sumber Jaya Kecamatan Waway Karya Kabupaten Lampung Timur beserta perangkatnya yang memainkan fungsi sebagai bagian dari suatu organisasi, yang diuraikan sebagai berikut :

$$
\begin{array}{ll}
\text { - Guru Negeri Sipil } & =11 \text { orang } \\
\text { - Guru Honorer } & =20 \text { orang } \\
\text { Jumlah Populasi } & =30 \text { orang. }(31-1)
\end{array}
$$

Berhubung jumlah populasi relatif kecil, maka penulis tidak mengadakan atau melakukan penarikan sampel untuk diteliti, karena dapat di jangkau seluruhnya. Hal ini berarti seluruh guru di SD Negeri 2 Sumber Jaya Kecamatan Waway Karya Kabupaten Lampung Timur menjadi responden atau sumber data (sampel jenuh) dalam penelitian ini dengan cara penyebaran kuesioner.

\subsection{Metode Analisis}

Setelah angket dibentuk maka pengujian menggunakan validitas digunakan. Tipe uji validitas yang digunakan adalah validitas konstruk (validity construct) yang menentukan validitas dengan cara mengkorelasikan antar skor yang diperoleh masing-masing item yang dapat berupa pertanyaan maupun pertanyaan dengan skor totalnya. Skor total ini merupakan nilai yang diperoleh dari penjumlahan semua skor item. Korelasi antara skor item dengan skor totalnya harus signifikan berdasarkan ukuran statistik. Bila ternyata skor semua item yang disusun berdasarkan dimensi konsep berkolerasi dengan skor totalnya, maka dapat dikatakan bahwa alat ukur tersebut mempunyai validitas.

Rumus korelasi yang digunakan dalam penelitian ini adalah rumus product- moment (Sugiyono, 2010) sebagai berikut :

$$
r_{b}=\frac{n\left(\sum \mathrm{XY}\right)-\left(\sum \mathrm{X}\right)\left(\sum \mathrm{Y}\right)}{\sqrt{\left[n \sum \mathrm{X}^{2}-\left(\sum \mathrm{X}\right)^{2}\right)\left(n \sum \mathrm{Y}^{2}-\left(\sum \mathrm{Y}\right)\right.}}
$$

Keterangan:

$r_{b}=$ Koefisien korelasi Pearson antar item instrumen yang akan digunakan dengan variabel yang bersangkutan

$X=$ Skor item instrumen yang akan digunakan

$\mathrm{Y}=$ Skor semua item instrumen dalam variabel tersebut

$\mathrm{n} \quad=$ Jumlah responden dalam uji coba instrumen

Uji Reliabilitas dilakukan untuk mengetahui tingkat konsistensi hasil pengukuran jika dilakukan pengukuran ulang terhadap gejala dan alat ukur yang sama. Yang dimaksud dengan reliabilitas adalah menunjukan pada suatu pengertian bahwa sesuatu instrumen cukup dapat dipercaya untuk digunakan sebagai alat pengumpulan data karena instrumen tersebut sudah baik. Reliabilitas menunjukkan tingkat keterandalan tertentu. Reliabel artinya, dapat dipercaya, jadi dapat diandalkan. (Arikunto, Suharsimi, 2012)

Regresi dan korelasi ; keduanya mempunyai pengaruh, dan atau hubungan erat. Setiap regresi pasti ada korelasinya, tetapi korelasi belum tentu dilanjutkan dengan regresi. korelasi yang tidak dilanjutkan dengan regresi adalah korelasi antara dua variabel yang tidak mempunyai hubungan sebab akibat atau hungungan fungsioal, analisis refresi dilakukan bila hubungan dua variabel berupa hubungan sebab akibat. Penelitian ini dilakukan untuk mengetahui pengaruh model pada masing-masing variabel independen, terhadap variabel dependen menggunakan regresi sederhana sebagai berikut : Arikunto ( 2012) 
Untuk melihat pengaruh, maka dihitung koefisien korelasinya dengan rumus dibawah ini :

$$
r X_{i} Y_{i}=\frac{n \Sigma X_{i} Y_{i}-\left(\Sigma X_{i}\right)\left(\Sigma Y_{i}\right)}{\sqrt{\left\{n \Sigma X_{i}^{2}-\left(\Sigma X_{i}\right)^{2}\right)\left\{n \Sigma Y_{i}^{2}-\left(\Sigma Y_{i}\right)^{2}\right\}}}
$$

Untuk diketahui apakah koefisien korelasi yang didapat ada artinya perlu diadakan pengujian statistik $f$ dengan rumus sebagai berikut :

$$
F=\frac{R^{2} / K}{\left(1-R^{2}\right) /(n-K-1)}
$$

$\mathrm{R}^{2}=$ koefisien korelasi $(\mathrm{r})$

$\mathrm{K}=$ jumlah variabel independen

$\mathrm{N}=$ jumlah anggota sampel

Jika ternyata perhitungan $\mathrm{F}>\mathrm{F}$ tabel maka terdapat hubungan yang sangat erat antara variabel independen dengan variabel dependen.

$$
R \rightarrow r x y=\frac{N \Sigma x y-(\Sigma x)(\Sigma y)}{\sqrt{\left\{N \Sigma x^{2}-\left(\Sigma x^{2}\right)\right\}\left\{N \Sigma y^{2}-\left(\Sigma y^{2}\right)\right\}}}
$$

Untuk mengetahui hubungan dua variabel independen terhadap variabel dependen harus dihitung korelasi ganda. Korelasi ganda bukan merupakan penjumlahan korelasi product moment sederhana antara satu variabel independen dengan variabel dependen, melainkan dengan rumus tersendiri korelasi ganda ( $R$ ) merupakan angka yang menunjukkan arah dan kuatnya hubungan antara dua variabel independen secara bersama-sama terhadap variabel dependen.

Jika setelah dihitung $\mathrm{F}>\mathrm{F}$ tabel, maka koefisien korelasi ganda berdasarkan perhitungan regresi ganda yang diuji signifikan, yaitu dapat diberlakukan ke populasi dengan taraf kesalahan $5 \%$ atau $1 \%$ guna mempercepat seluruh perhitungan diatas maka digunakan komputer program statistik. Dari pengolahan data dengan program statistik maka diperoleh hasil sebagai berikut :
a. Korelasi berganda, ukuran lain dan analisanya
b. Persamaan regresi berganda dan analisisnya

\section{c. Menguji koefisiensi regresi berganda}

\section{ANALISIS DAN PEMBAHASAN}

Sebelum dilakukan pengolahan data regresi berganda perlu dilakukan uji terhadap asumsi klasik untuk menghindari asumsi klasik yaitu uji normalitas, dan uji homogenitas. Uji Normalitas dengan menggunakan program SPSS 18, hasil uji normalitas yang dilakukan dapat dilihat dengan hasil grafik normalitas, yang ditampilkan sebagai berikut:

\section{Gambar 1 \\ Grafik Normalitas}

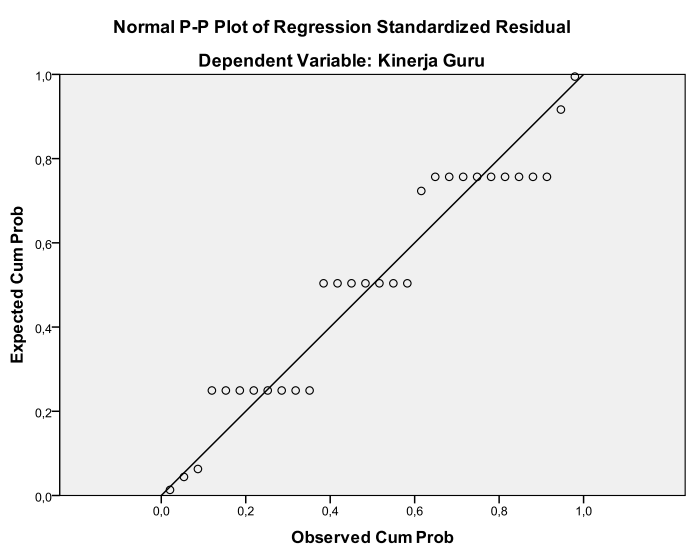

Sumber data : Grafik SPSS 18

Pola penyebaran yang terjadi berada pada sekitar garis diagonal dan mengikuti garis diagonal tersebut meskipun sedikit terpisah tetapi masih disekitaran sumbu normal. Ini berarti bahwa model regresi dalam penelitian ini sudah memenuhi asumsi normalitas dengan nilai moderate, yaitu variabel-variabel yang digunakan dalam penelitian ini mempunyai distribusi yang normal.

Untuk menguji homogenitas digunakan metode visual berdasarkan hasil olahan data dengan program SPSS 18 yaitu dengan cara melihat penyebaran nilai-nilai residual terhadap nilai prediksi.sebagai berikut : 
Gambar 2.

Grafik Scatterplot X1 dan Y

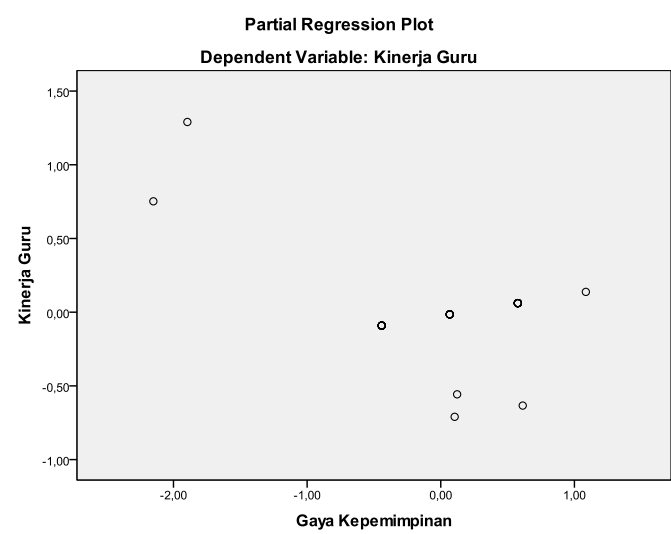

Sumber : Hasil Olah Data SPSS 18

Berdasarkan seluruh gambar grafik di atas, diketahui bahwa penyebaran nilai - nilai perbandingan tersebut tidak membentuk pola tertentu sehingga keadaan homogenitas dapat terpenuhi pada homogenitas Variabel $\mathrm{X} 1$ dan Variabel Y.

Gambar 3.

Grafik Scatterplot X2 dan Y

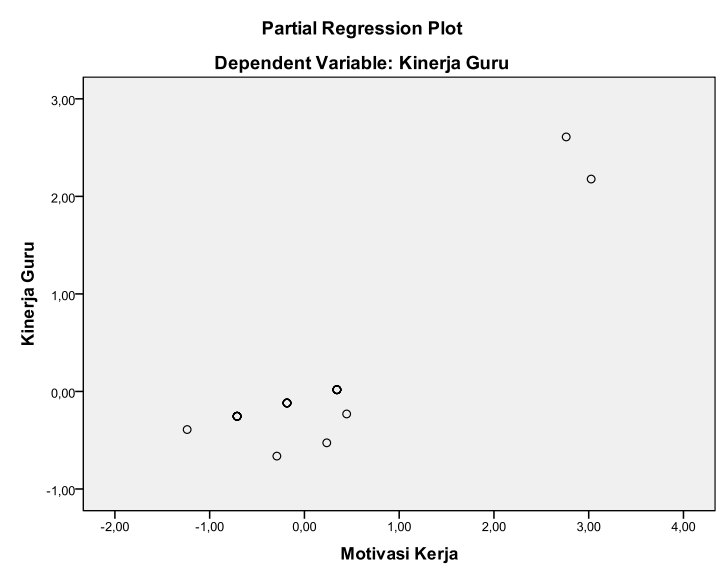

Berdasarkan seluruh gambar grafik di atas, diketahui bahwa penyebaran nilai - nilai perbandingan tersebut tidak membentuk pola tertentu sehingga keadaan homogenitas dapat terpenuhi pada homogenitas Variabel X2 dan Variabel Y. Maka berdasarkan hasil uji data Normalitas dan Homogentitas data penelitian dapat dilanjutkan ke uji selanjutnya yaitu regresi berganda.

Setelah uji Normalitas dan

Homogenitas terpenuhi maka data siap untuk dilakukan uji regresi berganda guna pembuktian hipotesis penelitian. Hasil uji regresi linear berganda yang dilakukan dengan menggunakan program SPSS 18 dengan acuan hasil perhitungan analisis statistik data dijelaskan sebagai berikut:

Model persamaan regresi untuk fungsi ini adalah : (dirinci)

1. Pada Hipotesis Parsial $Y=\alpha+B_{1} X_{1}$ (Hipotesis I)

$Y=\alpha+B_{2} X_{2} \quad$ (Hipotesis II)

2. Pada Hipotesis Simultan $Y=\alpha$ $+\mathrm{B}_{1} \mathrm{X}_{1}+\mathrm{B}_{2} \mathrm{X}_{2} \quad$ (Hipotesis III)

Dimana :

$Y=$ Kinerja Pegawai

$X_{1}=$ Gaya Kepemimpinan

$\mathrm{X}_{2}=$ Motivasi Kerja

$\alpha=$ konstanta

$\mathrm{B}_{1}, \mathrm{~B}_{2},=\quad$ koefisien regresi

Berdasarkan hasil analisis data maka hasil analisis yang didapatkan adalah sebagai berikut:

Sumber : Hasil Olah Data SPSS 18

Tabel 1.

Hasil Analisis Model Summaryb

\begin{tabular}{|c|c|c|c|c|}
\hline Model & $\mathrm{R}$ & R Squares & Adjusted R Square & $\begin{array}{l}\text { Std. Error of } \\
\text { the Estimate }\end{array}$ \\
\hline 1 & ,0986a & ,972 & ,970 &, 30775 \\
\hline
\end{tabular}

a. Predictors : (Constant), Motivasi Kerja, Gaya Kepemimpinan

b. Dependent Variable : Kinerja Guru 
Tabel 2.

Anovab $^{b}$

\begin{tabular}{llrrrrr}
\hline Model & & Sum of Squares & df & Mean Square & $F$ & Sig. \\
\hline \multirow{3}{*}{1} & Regression & 90,243 & 2 & 45,121 & 476,407 &, $000^{\mathrm{a}}$ \\
\cline { 2 - 8 } & Residual & 2,557 & 27 & 0,95 & & \\
\cline { 2 - 7 } & Total & 92,800 & 29 & & & \\
\hline
\end{tabular}

a. Predictors : (Constant), Motivasi Kerja, Gaya Kepemimpinan

b. Dependent Variable : Kinerja Guru

Tabel 3.

Coefficients

\begin{tabular}{|c|c|c|c|c|c|c|}
\hline \multirow{2}{*}{ Model } & & \multicolumn{2}{|c|}{$\begin{array}{c}\text { Unstandardized } \\
\text { Coefficients }\end{array}$} & \multirow{2}{*}{$\begin{array}{c}\begin{array}{c}\text { Standardized } \\
\text { Coefficients }\end{array} \\
\text { Beta }\end{array}$} & \multirow{2}{*}{$\mathrm{t}$} & \multirow{2}{*}{ Sig. } \\
\hline & & B & $\begin{array}{l}\text { Std. } \\
\text { Error }\end{array}$ & & & \\
\hline \multirow{3}{*}{1} & (Constant) & 18,523 & ,189 & & 98,087 &, 000 \\
\hline & Gaya Kepemimpinan &,- 265 & ,081 &,- 432 & $-3,265$ & ,003 \\
\hline & Motivasi Kerja & 659 & ,062 & 1,400 & 10,579 &, 000 \\
\hline
\end{tabular}

Sumber Hasil Oleh Data SPSS 18

Berdasarkan hasil uji tersebut maka didapatkan persamaan model regresi yang sebagai berikut

$Y=18.523+-0.265 \times 1+0.659 \times 2$

$t_{\text {hitung }}=(98.087) \quad(-3.265) \quad(10.579)$

$\mathrm{R}^{2} \quad=0.972$

$\mathrm{F} \quad=476.407($ Prob.sig $=0,000)$

$\mathrm{N} \quad=30$

Dari hasil regresi yang telah didapat, maka dapat hasil penelitian dapat diinterpretasikan pada diketahui bahwa nilai $\mathrm{F}$ hitung sebesar $476.407>3.316$ dan $F$ signifikansi adalah $0.000<0.05$ yaitu pada tingkat signifikansi $95 \%$ yang berarti sahih. Dengan demikian maka Ho ditolak, berarti koefisien regresi signifikan dan menerima asumsi linieritas. Kemudian pada uji $t$ yang dilakukan untuk melihat besarnya pengaruh secara individu variabel bebas terhadap variabel tak bebas.

Dan hasil estimasi dapat kita lihat bahwa nilai t hitung untuk variabel (X1) sebesar
$-3.265>-1.70$ (indeks cerminan) (Prob.sig. = $0,003)$ dan untuk variabel $(X 2)$ sebesar 10.579 $>1.70$ (Prob.sig. $=0,000$ ) yang berarti t hitung $>\mathrm{t}$ tabel dengan tingkat signifikansi $95 \%$ (persen). Hal ini menunjukkan bahwa koefisien masing variabel bebas adalah penting secara statistik pengaruhnya terhadap variabel tak bebasnya atau dengan kata lain bahwa berpengaruh Signifikan baik secara parsial maupun simultan.

Kemudian koefisien determinasi X1,X2 - $Y\left(R^{2}\right)$ besar yaitu sebesar 0.972 Berarti bahwa $97.2 \%$ (persen) dari variasi perubahan pengaruh Gaya Kepemimpinan dan Motivasi Kerja dapat menjelaskan Kinerja Pegawai di Sekolah SD Negeri 2 Sumber Jaya Kecamatan Waway Karya Kabupaten Lampung Timur . Sedangkan $2.8 \%$ (persen) sisanya adalah pengaruh dari variabel atau faktor-faktor lain diluar model. Setelah dilakukan pengujian dan pembuktian hipotesis 3 (Simultan atau secara bersama - sama), selanjutnya hasil regresi linier berganda diartikan sebagai berikut : 
Gambar 4.

Rangkuman Hasil Analisis Penelitian

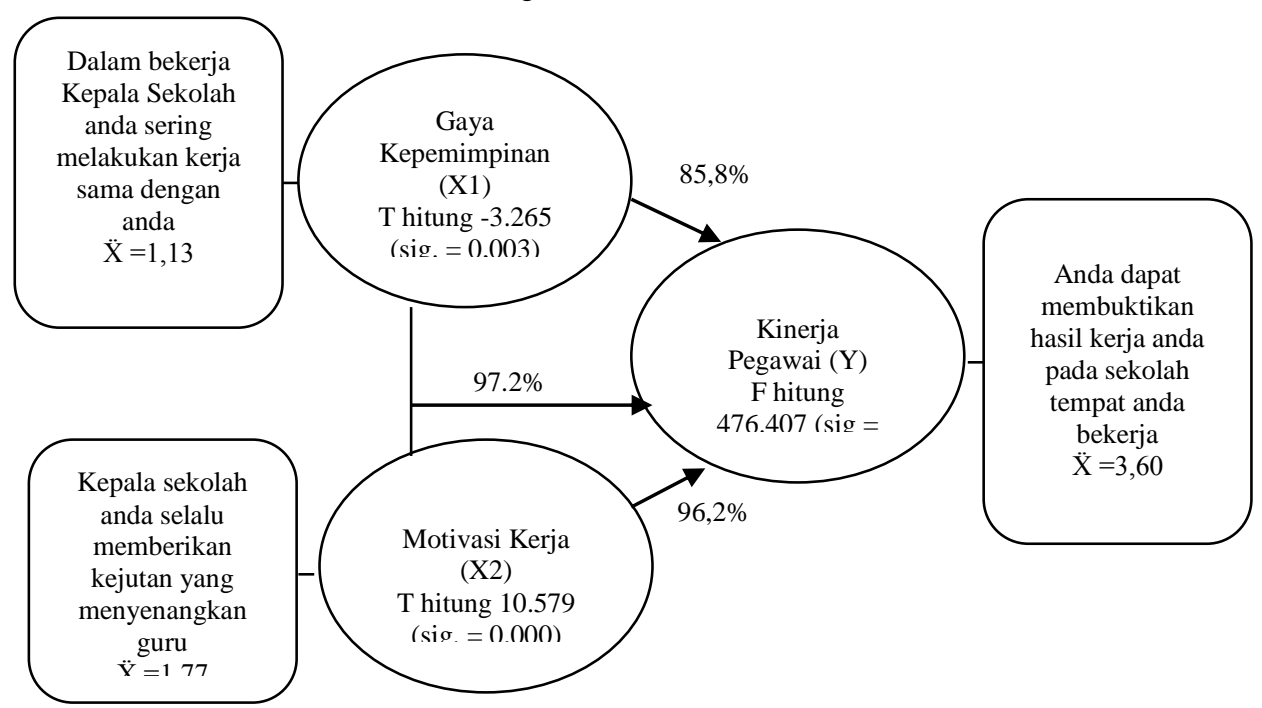

Sumber : Rangkuman Hasil Analisis SPSS 18

\section{SIMPULAN DAN SARAN}

\subsection{Simpulan}

Berdasarkan hasil rangkuman analisis tersebut maka gambar tersebut dapat diinterpretasikan bahwa gaya kepemimpinan berpengaruh terhadap kinerja dan motivasi kerja memiliki pengaruh yang besar (97.2\%) terhadap kinerja pegawai di Sekolah SD Negeri 2 Sumber Jaya Kecamatan Waway Karya Kabupaten Lampung Timur dengan variabel motivasi kerja sebagai variabel dominan yang mempengaruhi kinerja pegawai di Sekolah SD Negeri 2 Sumber Jaya Kecamatan Waway Karya Kabupaten Lampung Timur dengan pengaruh sebesar (96.2\%) tetapi tidak dapat menghilangkan variabel Gaya Kepemimpinan meskipun memiliki kontribusi yang negatif disebabkan sahih.

Pada variabel Gaya Kepemimpinan juga didapatkan bahwa Dalam bekerja Kepala Sekolah anda sering melakukan kerja sama dengan anda memiliki rata - rata yang paling kecil sebesar 1.13. Pada Variabel Motivasi Kerja juga didapatkan Kepala sekolah anda selalu memberikan kejutan yang menyenangkan guru memiliki rata-rata yang paling kecil sebesar 1.77. Kemudian Pada variabel Kinerja Pegawai didapatkan Anda dapat membuktikan hasil kerja anda pada sekolah tempat anda bekerja memiliki rata rata yang paling kecil sebesar 3.60. Dari pengolahan data juga didapatkan bahwa masih ada variabel lain sebesar $2.8 \%$ yang belum dimasukkan tetapi memiliki pengaruh pada Kinerja Pegawai di Sekolah SD Negeri 2 Sumber Jaya Kecamatan Waway Karya Kabupaten Lampung Timur dan bersifat laten.

\subsection{Saran}

Memperbaiki kemampuan Kepala Sekolah agar selalu memiliki ide penyelesaian yang baik bagi pekerjaan guru, kemampuan kepala sekolah atau pimpinan dalam bekerja untuk sering melakukan kerja sama dengan pegawai lebih intensif agar tidak memberikan effek negatif, pemberian petunjuk oleh Kepala Sekolah pada guru di setiap pekerjaan dengan jelas, dan panduan delegasi ketika Kepala Sekolah tidak ditempat.

Sistem penghargaan Kepala sekolah atau pimpinan dalam memberikan kejutan atau penghargaan yang menyenangkan pegawai dan guru, membuat tempat guru bekerja mendukung keberhasilan kerja guru, menciptakan iklim untuk menjadi guru yang terbaik, pengawasan yang baik, pembuatan peraturan kerja yang lebih dinamis, menciptakan prinsip kehati-hatian dalam bekerja disebabkan adanya hukuman atau sangsi dari pimpinan sekolah. Mempertahankan sistem pelaporan kegiatan pegawai dan guru sehingga mereka dapat 
membuktikan hasil kerjanya pada sekolah tempat mereka bekerja dengan cara sistem laporan tertulis agar kinerja yang baik dapat tercapai.

\section{DAFTAR PUSTAKA}

Arikunto, Suharmini.2012, Manajemen Penelitian, Jakarta, Rineka Cipta.

Ahmadi, A dan S. Widodo. 2013. Psikologi Belajar. Jakarta : Rineka Cipta.

Cohen, William, 2011, Setiap Pemimpin Harus Baca Buku ini, Jakarta, Tangga Pustaka.

Darsono. 2011. Manajemen Sumber Daya Manusia Abad 21. Jakarta : NC Consultan.

Davis Keith, New Strom, Jhon W. 2012, alih bahasa Agus Dharma, Perilaku Dalam Organisasi, Jilid I, Erlangga, Jakarta.

Edy Irawan Arief. (2011). Pedoman Penulisan Tesis. Program Pasca Sarjana. Bandar Lampung : USBRJ.

Greenberg dan Baron. (2013). Behaviorin Organizations. New Jersey : Prentice hall Internasional Inc.

Haryono, Siswoyo, 2010, Intisari Teori Kepemimpinan, Jakarta, PT. Intermedia Personalia Utama.

Junaidi. (2010) http://wawanjunaidi.blogspot.com/2010/01/teoriteori-kepemimpinan.html

Luthan, 2012. Maslow Motivation Hierarchy. International Edition. New York: The McGraw-Hill Companies, Inc

Mangkunegara. (2009). Manajemen Sumber Daya Manusia Perusahaan. Bandung : PT. Remaja Rosdakarya

Miftah Thoha, 2013. Prilaku Organisasi Konsep Dasar Dan Aplikasinya. Jakarta: Raja Grafindo Persada.

Masaong, Kadim, Arfan A, Tilomi, 2011, Kepemimpinan Berbasis Multiple Intelligence, Bandung, Alfabeta.
Masaong, Tilomi, 2011, Kepemimpinan Berbasis Multiple Intelligence, Bandung, Alfabeta.

Mintzberg, H., Bruce, A. \& Joseph, L. 2010. Strategy Safari: A Guided Tour through the Wilds of Strategic Management. New York: The Free Press.

Nimran Umar. 2014. Perilaku Organisasi. Cetakan Ketiga. Surabaya: CV. Citra Media.

Robbins Stephen P., 2012. Organizational Behavior. Jilid 1. Edisi Kedelapan. Jakarta: PT. Bhuana Ilmu Populer.

Rivai, Veithzal dan Mulyadi, Dedy, 2010, Kepemimpinan dan Perilaku Organisasi, Jakarta, Rajawali Press.

Rivai, Veithzal dan Sagala, 2011, Manajemen Sumber Daya Manusia untuk Perusahaan Dari Teori ke Praktik, Jakarta, Rajawali Press.

Sardiman. (2014). Interaksi Motivasi Belajar Mengajar. Jakarta : Raja Grafindo Persada.

Siagian, S.P. (2012). Manajemen Sumber Daya Manusia. Cetakan Kedelapan. PT. Bumi Aksara. Jakarta.

Slameto. (2015). Belajar dan Faktor-faktor yang mempengaruhinya. Bandung : Rineka Cipta.

Syamsuddin. (2013). Psikologi Pendidikan. Bandung PT. Remaja Rosda Karya.

Sutrisno Edy. (2011). Manajemen Sumber Daya Manusia. Jakarta : Kencana

Sekaran Uma. 2010, Research Methods For Business, New York :John Wiley \& Sons, Inc.

Siagian Sondang P., 2012. Kiat Meningkatkan Produktivitas Kerja, Cetakan Pertama, , Jakarta: PT. Rineka Cipta.

Sugiono, 2010 Metode Penelitian Pendidikan, Penerbit Alfabeta, Bandung. 2010.

Thomas R, Dye 2010 Understanding Public Policy, Prentice-Hall, Inc, Englewood Cliffs, New Jersey. 